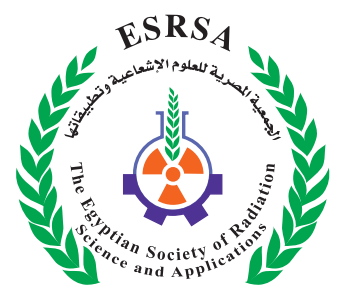

\title{
Detection of generated free radicals, lipid peroxidation and some trace elements status in Egyptian patients with chronic hepatitis C.
}

\author{
Abdel Fattah, S.M. ${ }^{1}$; Yousri, R.M. ${ }^{2 *}$; Abdallah, N.M. ${ }^{3}$; Abdel Hamid, F.F. ${ }^{3}$ and El-Rouby M.N. ${ }^{4}$
}

Received: 12/03/2019

Accepted: 09/05/2019

E-mail: raafatyousri@hotmail.com

\section{KEYWORDS}

Chronic hepatitis $C$, oxidative stress, Trace elements, $\mathrm{Ca}$, iCa.

\section{ABSTRACT}

Hepatitis $\mathrm{C}$ virus $(\mathrm{HCV})$ is the etiological agent accounting for chronic liver disease in approximately $2-3 \%$ of the population worldwide. In Egypt, HCV infection has become one of the national health problems. The aim of the suggested study was to investigate if any correlation exists between total free radicals generated in chronic hepatitis $\mathrm{C}$ patients and some trace elements in blood and urine. The study included 104 subjects, 22 healthy controls and 82 CHC patients grouped as follows: Gr I (control group), Gr II [compensated chronic liver disease (without cirrhosis)], Gr III [decompensated liver cirrhosis (with cirrhosis)] and Gr IV [(hepatocellular failure (end stage liver disease)].

Correlations of total free radicals and malondialdehyde (MDA) with other trace elements were studied in different groups. Blood and urinary trace elements concentrations varied among the different stages of $\mathrm{HCV}$ patients studied groups. The correlation coefficient between the different variables independently changed. Results of the present study revealed that total free radicals, MDA, blood copper $(\mathrm{Cu})$, urinary zinc $(\mathrm{Zn})$ as well as the total calcium (Ca) and ionized calcium (iCa) concentrations were significantly increased in all CHC patients groups, while blood Zinc (Zn) and selenium (Se) concentrations were significantly decreased in all $\mathrm{CHC}$ patients groups compared to those of control group.

1. Drug Radiation Research Department,

2. Radiobiology Research Department, National Center for Radiation Research and Technology (NCRRT) Atomic Energy Authority (AEA)

3. Biochemistry Department, Faculty of Science, Ain Shams University

4. Department of Cancer Biology, Virology and Immunology Unit, National Cancer Institute, Cairo University, Egypt 
The urinary cupper $(\mathrm{Cu})$ concentration was significantly elevated only in Gr II. Gr III and Gr IV showed significant low values of blood iron $(\mathrm{Fe})$. Conclusion: blood and urinary trace elements profile was suggested to be a good indicator for assessing liver damage in chronic HCV patients. Oxidative stress with subsequent increase or decrease in blood and urinary trace elements in hepatitis $\mathrm{C}$ infected individuals could happen at various stages of liver damage causing impairment in the levels of measured trace elements. The correlation between trace elements and either total free radicals or MDA showed different pattern according to the stage of the disease.

\section{INTRODUCTION}

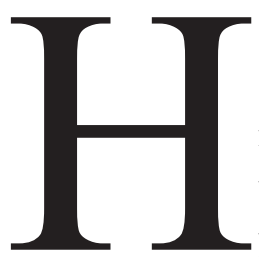

epatitis $\mathrm{C}$ virus (HCV) accounts for approximately 3-4 million new cases $(2-3 \%$ of the population worldwide) of viral hepatitis each year and it is a human pathogen.

In contrast to hepatitis A, B and $\mathrm{E}$ infected patients; chronic hepatitis $\mathrm{C}$ patients develop chronic disease $(\mathrm{CHC})$ in most cases $(>80 \%)$ with increasing risk of developing liver cirrhosis and HCC (Ivanov et al., 2013). The highest estimated prevalence of HCV has been reported in Egypt with $11-14 \%$ of the population chronically infected with the virus (Frank $\boldsymbol{e t}$ al., 2000). This is ten times greater than any other country in the world (Mohammed et al., 20122).

Numerous experimental findings have underlined the relationship between liver damage and the production of oxygen-derived free radicals during inflammation (Contreras-Zentella and Hernández-Muñoz, 2016). In CHC, liver damage may be attributed to altered oxide-reductive balance (oxidative stress) and glutathione turnover (Kohchi et al., 2009; West et al., 2011). Patients with $\mathrm{CHC}$ exhibit an increased production of tumor necrosis factor- $\alpha$ (TNF- $\alpha$ ), a cytokine that can produce oxidative stress by stimulating the generation of reactive oxy- gen species (ROS) (Ivanov et al., 2013). CHC induces a state of hepatic oxidative stress that is more pronounced than that present in many other inflammatory liver diseases (Korenaga et al. 2005a),

Since the metabolism of trace elements takes place in the liver, the concentration of each trace element may be varied with different types of liver disease. The relationship between chronic hepatitis and trace elements has not been understood clearly. Different types of liver diseases induce different pattern of the concentration of each trace element because these elements may have a direct hepatic toxicity or may be decreased as a consequence of the impaired liver function (Meran et al., 2004). Among these trace elements, zinc ( $\mathrm{Zn}$ ) which plays an important role in the function of the liver and affect growth and integrity of the immune system (Mohammed $\boldsymbol{e t}$ al., 2010). The liver is the main iron storage organ and it plays a fundamental role in iron metabolism (Sebastiani et al., 2006). The increase in iron stores (increase in serum ferritin and transferrin iron saturation) leads to increased response to $\mathrm{HCV}$ infection, and progression of chronic hepatitis $\mathrm{C}$ which is a key link between iron metabolism and pathophysiology of viral hepatitis.

As the disease progresses from chronic hepatitis to liver cirrhosis, copper levels increase. Copper acts as a cofactor against hepatic fibrosis in chronic liver diseases, particularly in the biosynthesis of collagen.

Magnesium $(\mathrm{Mg})$ is an essential cofactor of numerous cellular enzymes including mitochondrial superoxide dismutase. The major route of elimination is biliary with very little excreted in urine (Bourre, 2006).

Oxygen free radicals generated in $\mathrm{CHC}$ patients lead to the inactivation of enzymes and increase of intracellular calcium $\left(\left[\mathrm{Ca}^{2+}\right] \mathrm{i}\right)$ level, both of which in turn could activate various degradative pathways in the working muscle cells (Boffi et al., 2002). It has been reported that the oxidation of a small, but 
critical, pool of protein thiols can cause an irreversible damage to hepatocytes as a result of a rise of cytosolic $\mathrm{Ca}^{2+}$ concentration, followed by activation of cytosolic proteolytic systems and phospholipids hydrolysis (Nicotera et al., 1986). Perturbation of hepatic $\mathrm{Ca}^{2+}$ homeostasis was also associated with modulation of processes such as gluconeogenesis, glycogenolysis, respiration, and cell division (Bygrave and Benedetti, 1993).

Rashid (2011); Nazir et al., (2013) documented that profile of metals like $\mathrm{Cu}, \mathrm{Se}$ and $\mathrm{Zn}$ for the diagnosis of liver disease as well as other diseases like cancer is highly sensitive.

The present work aimed to evaluate the total free radical concentration measured by Electron Spin Resonance (ESR) technique and estimation of the correlation with malondialdehyde concentration in different hepatitis $\mathrm{C}$ patients group, in addition to measurements of several blood and urinary trace elements.

\section{SUBJECTS AND METHODS}

The study included 104 subjects, 22 healthy subjects chosen randomly and considered as a control group and 82 chronic hepatitis $\mathrm{C}$ (CHC) patients. The study was conducted at inpatient clinic of El- Sayed Galal Hospital - Internal Medicine Department. The choice of patients was carried out by the physicians of the hospital. Patients and controls were classified into four groups. Patients groups were divided according to the degree of the pathological severity of the disease into 4 groups (Table 1).

All patients were Enzyme Linked Immunosorbent Assay (ELISA) antibody positive for $\mathrm{HCV}$ and with signs of chronic hepatitis justified by clinical examination, laboratory findings, abdominal ultrasonographic examination and/or histopathological examination of a needle liver biopsy.

All subjects received oral informed consent to participate in the study, which was approved by the local ethics committee.

Table (1): Characteristics of the hepatitis $C$ patients.

\begin{tabular}{|c|c|c|c|c|}
\hline Feature Group & $\begin{array}{c}G r I \\
(n=22)\end{array}$ & $\begin{array}{c}\text { Gr II } \\
(n=30)\end{array}$ & $\begin{array}{c}G r I I I \\
(n=30)\end{array}$ & $\begin{array}{c}G r I V \\
(n=22)\end{array}$ \\
\hline Male/female & $14 / 8$ & $20 / 10$ & $21 / 9$ & $16 / 6$ \\
\hline $\begin{array}{l}\text { Age (years) } \\
\text { Range } \\
\text { Mean } \pm S D\end{array}$ & $\begin{array}{c}25-75 \\
46.14 \pm 15.16\end{array}$ & $\begin{array}{c}24-60 \\
51.9 \pm 8.73\end{array}$ & $\begin{array}{c}45-65 \\
53.40 \pm 5.40\end{array}$ & $\begin{array}{c}35-75 \\
55.32 \pm 11.96\end{array}$ \\
\hline $\begin{array}{c}\text { Duration of infection (years) } \\
\text { Range } \\
\text { Mean } \pm S D\end{array}$ & ---- & $\begin{array}{c}1-10 \\
4.13 \pm 3.11\end{array}$ & $\begin{array}{c}1-10 \\
4.70 \pm 2.98\end{array}$ & $\begin{array}{c}2-20 \\
10.18 \pm 5.33\end{array}$ \\
\hline Diabetes & $18 \%$ & $65 \%$ & $40 \%$ & $31 \%$ \\
\hline PCR & - ve & $70 \%$ & $50 \%$ & $45 \%$ \\
\hline
\end{tabular}

Group I: healthy (Control group)

Group II: compensated chronic liver disease (CLD) (non cirrhotic) patients

Group III: decompensated liver cirrhosis (LC) (cirrhotic) patients.

Group IV: chronic hepatitis patients with hepatocellular failure (end stage liver disease) 


\section{Blood sampling}

10 millimeters of venous blood samples were collected using disposable plastic syringes and divided into 2 portions:

- The first was collected into test tubes containing heparin as an anticoagulant for detection of free radicals and trace elements.

- The second portion was collected in dry test tubes for separation of serum for the evaluation of malondialdehyde (MDA), reverse transcriptase polymerase chain reaction (RT-PCR) and simple liver function tests.

\section{Urin sampling}

The assigned urine samples in this study were collected in diposable clean urine cups of approximately $25 \mathrm{ml}$ sample for control and case subjects.

\section{Methods}

$\mathrm{HCV}$ reverse transcriptase- polymerase chain reaction (RT-PCR) of blood samples were carried out according to the method described by Attia et al., (1996).

Assay of trace elements was carried out using atomic absorption technique.

Total free radicals level was assayed by electron spin resonance technique (ESR) according to the method of Heckly (1972; 1976). Determination of lipid peroxidation was carried out by estimation of malondialdehyde level according to the method described by Yoshioka et al., (1979).

\section{Statistical Analysis}

collected data were presented as means \pm standard deviation of the means. The statistical analysis was performed using Student t-test by Prism Dimo4 program and Origin 6.1. The method used for the analysis of the results is that given by Milton $\boldsymbol{e t}$ al. (1986).

\section{Analysis ESR Data.}

For monitoring variations in the peak height EPR signals (Fig. 1) as a function of magnetic field, intensities were measured by the use of Bruker EMX Electron Spin Spectrometer as the distance between top and bottom points of the first derivative recorded according to Gohn (1986) and Passcual, et al. (2002). Quantitative assessments of free radical concentrations were, however, made by the following equation:

For the experimental data, the number of radicals is given by:

$$
N d=K .\left[H o(\Delta H)^{2} A / 2\right] /[H m G e \sqrt{P H}\rfloor
$$

\section{Where:}

$\mathrm{Nd}$ : number of radicals.

$\mathrm{K}$ : factor depending on the experimental condition of spectrophotometer $=10^{3} / \mathrm{cm}$

Ho: Magnetic field at peak in gauss.

$\Delta \mathrm{H}$ : width peak to peal.

Hm: modulation field.

PH: Power in $\mathrm{mW}=1.008 \mathrm{~mW}$.

Ge: gain of the detector $=3.17 \mathrm{e}^{+05}$

Concentration $=$ unpaired electrons $/ \mathrm{g}$ or spin $/ \mathrm{g}$

Where: $\mathrm{g}=$ gram.

A: peak height of signal/ weight

\section{RESULTS}

\section{Total free radicals and malondialdehyde (MDA) concentrations:}

Blood total free radicals concentrations showed a highly significant increase in $\mathrm{CHC}$ patients with and without cirrhosis (Gr II \& Gr III) $(\mathrm{p}<0.01 \&$ $0.001)$ and a significant increase in end stage of liver disease $(\mathrm{Gr}$ IV) $(\mathrm{p}<0.05)$ compared to those of the 
control group. Serum MDA concentrations showed $<0.001 \& 0.01)$ compared to those of the control a highly significant increase in all patient groups ( $\mathrm{p}$ group.

Table (2) : Total free radicals (radical/ $\mathrm{g}$ ) and malondialdehyde (MDA) (nmol/ml) concentrations in control and CHC patients groups.

\begin{tabular}{|c|c|c|c|}
\hline Groups & Parameters & $\begin{array}{c}\text { Total Free Radical } \\
\text { concentration } \\
\text { (Radical/g) X 10 }\end{array}$ & $\begin{array}{c}\text { Malondiadehyde } \\
\text { (MDA) } \\
\text { (nmol/ml) }\end{array}$ \\
\hline $\begin{array}{c}G I \\
(\mathrm{n}=22)\end{array}$ & $\begin{array}{c}\text { Range } \\
\text { Mean } \pm \text { SD }\end{array}$ & $\begin{array}{c}0.11-1.027 \\
0.26 \pm 0.28\end{array}$ & $\begin{array}{c}1.76-7.7 \\
3.51 \pm 1.55\end{array}$ \\
\hline $\begin{array}{c}G I I \\
(\mathrm{n}=30)\end{array}$ & $\begin{array}{c}\text { Range } \\
\text { Mean } \pm \text { SD } \\
p_{1}< \\
\% \text { change }\end{array}$ & $\begin{array}{c}1.64-85.9 \\
17.84 \pm 25.8 \\
0.01 \\
6761.5 \%\end{array}$ & $\begin{array}{c}5.4-158.5 \\
48.31 \pm 56.12 \\
0.001 \\
1275.5\end{array}$ \\
\hline $\begin{array}{c}G I I I \\
(\mathrm{n}=30)\end{array}$ & $\begin{array}{c}\text { Range } \\
\text { Mean } \pm \text { SD } \\
\mathbf{p}_{1}< \\
\% \text { change }\end{array}$ & $\begin{array}{c}1.63-67 \\
12.86 \pm 18.8 \\
0.01 \\
4846.1\end{array}$ & $\begin{array}{c}12.5-144.2 \\
37.9 \pm 43.69 \\
0.001 \\
979.15\end{array}$ \\
\hline $\begin{array}{c}G I V \\
(\mathrm{n}=22)\end{array}$ & $\begin{array}{c}\text { Range } \\
\text { Mean } \pm \text { SD } \\
\mathbf{p}_{1}< \\
\% \text { change }\end{array}$ & $\begin{array}{c}1.6-99.45 \\
10.04 \pm 21 \\
0.05 \\
3761.53\end{array}$ & $\begin{array}{c}6.7-149.2 \\
33.19 \pm 44.67 \\
0.01 \\
845.6\end{array}$ \\
\hline
\end{tabular}

Group I: healthy (Control group)

Group II: compensated chronic liver disease (CLD) (non cirrhotic) patients

Group III: decompensated liver cirrhosis (LC) (cirrhotic) patients.

Group IV: chronic hepatitis patients with hepatocellular failure (end stage liver disease)

$p<0.05$ significant correlation must be written under all table

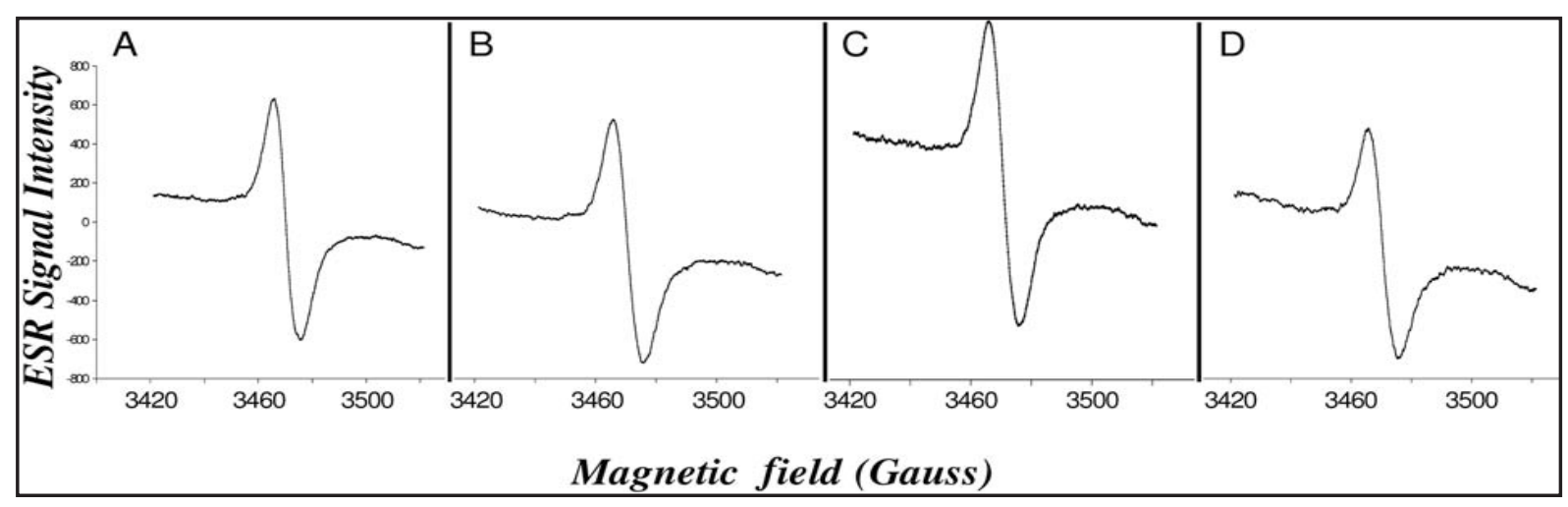

Fig. (1): ESR spectra of lyophilized blood samples.

\section{Blood Trace elements Table (3)}

Blood $\mathrm{Cu}$ levels showed a highly significant increase in non cirrhotic and cirrhotic patients groups (Gr II \& Gr III) and in end stage liver disease group
(Gr IV) $(\mathrm{p}<0.001 \& 0.01)$ when compared to the values of the control group.

Blood Zn levels showed a highly significant decrease in all patients groups $(\mathrm{p}<0.001 \& 0.01)$ in 
comparison with those of the control group.

Blood Fe levels showed non-significant decrease in non cirrhotic patients group (Gr II), as well as a significant decrease in cirrhotic patients group ( $\mathrm{Gr}$ III) $(p<0.05)$ in addition to a highly significant decrease in patients with end stage liver disease group (Gr IV) $(\mathrm{p}<0.01)$ compared to the levels of the control group.
Blood Mg concentrations showed non significant increase in all patients groups compared to the corresponding values of the control group.

Blood Se levels showed highly significant decrease in non cirrhotic patients group (Gr II), cirrhotic patients group (Gr III) and patients with end stage liver disease group $(\mathrm{p}<0.01 \& 0.001)$ against to the values of control group.

Table (3) : Blood. Cu, Zn, Mg and Se (ng/g) concentrations and in control and CHC patients groups.

\begin{tabular}{|c|c|c|c|c|c|c|}
\hline \multicolumn{2}{|c|}{$\begin{array}{ll}\text { Groups } & \text { Parameters } \\
\end{array}$} & $\begin{array}{l}\text { B. } \mathrm{Cu} \\
\mathbf{u g} / \mathrm{g}\end{array}$ & $\begin{array}{l}\text { B. Zn } \\
\text { ug/g }\end{array}$ & $\begin{array}{l}\text { B. Fe } \\
\text { ug/g }\end{array}$ & $\begin{array}{c}\text { B.Mg X10 } \\
\text { ug/g }\end{array}$ & $\begin{array}{l}\text { B. Se } \\
\mathrm{ng} / \mathrm{g}\end{array}$ \\
\hline $\begin{array}{c}G I \\
(\mathrm{n}=22)\end{array}$ & $\begin{array}{c}\text { Rang } \\
\text { Mean } \pm \text { SD }\end{array}$ & $\begin{array}{l}36.03-68.92 \\
53.82 \pm 9.36\end{array}$ & $\begin{array}{c}3.12-7.4 \\
4.53 \pm 1.07\end{array}$ & $\begin{array}{l}209.1-592 \\
294 \pm 73.91\end{array}$ & $\begin{array}{c}0.93-1.61 \\
1.196 \pm 0.17\end{array}$ & $\begin{array}{c}55-153 \\
107 \pm 31.03\end{array}$ \\
\hline $\begin{array}{c}G I I \\
(\mathrm{n}=\mathbf{3 0})\end{array}$ & $\begin{array}{c}\text { Range } \\
\text { Mean } \pm \text { SD } \\
\mathbf{p}_{1}< \\
\% \text { change }\end{array}$ & $\begin{array}{c}48.63-137.2 \\
72.09 \pm 20.63 \\
0.001 \\
34\end{array}$ & $\begin{array}{c}0.86-7.2 \\
2.82 \pm 1.47 \\
0.001 \\
-37.8\end{array}$ & $\begin{array}{c}174.6-527.9 \\
289.5 \pm 77.66 \\
\text { N.S } \\
-1.53\end{array}$ & $\begin{array}{c}0.93-2.16 \\
1.325 \pm 0.28 \\
\text { N.S } \\
10.8\end{array}$ & $\begin{array}{c}0-198 \\
60.06 \pm 64.56 \\
0.01 \\
-43.87\end{array}$ \\
\hline $\begin{array}{c}G I I I \\
(\mathbf{n}=30)\end{array}$ & $\begin{array}{c}\text { Range } \\
\text { Mean } \pm \text { SD } \\
\mathbf{p}_{1}< \\
\% \text { change }\end{array}$ & $\begin{array}{c}40.61-91.53 \\
69.43 \pm 15.57 \\
0.001 \\
28.8\end{array}$ & $\begin{array}{c}0.49-7.1 \\
2.99 \pm 2.03 \\
0.01 \\
-33.55\end{array}$ & $\begin{array}{c}158.1-371.1 \\
245.2 \pm 77.42 \\
0.05 \\
-16.6\end{array}$ & $\begin{array}{c}1.048-1.563 \\
1.26 \pm 0.15 \\
\text { N.S } \\
.35\end{array}$ & $\begin{array}{c}0-139 \\
36.51 \pm 46.63 \\
0.001 \\
-65.87\end{array}$ \\
\hline $\begin{array}{c}G I V \\
(\mathrm{n}=22)\end{array}$ & $\begin{array}{c}\text { Range } \\
\text { Mean } \pm \text { SD } \\
p_{1}< \\
\% \text { change }\end{array}$ & $\begin{array}{c}44.39-93.37 \\
68.93 \pm 15.38 \\
0.001 \\
28\end{array}$ & $\begin{array}{c}0.34-6.72 \\
3.11 \pm 1.46 \\
0.001 \\
-31.23\end{array}$ & $\begin{array}{c}147.8-398.1 \\
237.7 \pm 61.62 \\
0.01 \\
-19.14\end{array}$ & $\begin{array}{c}1.043-1.769 \\
1.26 \pm 0.179 \\
\text { N.S } \\
5.35\end{array}$ & $\begin{array}{c}0-34.7 \\
13.53 \pm 10.59 \\
0.001 \\
-87.35\end{array}$ \\
\hline
\end{tabular}

Group I: healthy (Control group)

Group II: compensated chronic liver disease (CLD) (non cirrhotic) patients

Group III: decompensated liver cirrhosis (LC) (cirrhotic) patients.

Group IV: chronic hepatitis patients with hepatocellular failure (end stage liver disease)

B. Cu (Blood copper) B. Zn (Blood zinc)

B. Fe (Blood iron) B. Se (Blood selenium)

B. $\mathrm{Mg}$ (Blood magnesium)

\section{Urinary Trace Elements Table (4):}

Urinary $\mathrm{Cu}$ concentrations showed significant increase in non cirrhotic patients group (Gr II) $(\mathrm{p}<$ 0.05 ) and a non significant increase in other patients groups when correlated to the values of the control group.
Urinary Zn levels showed highly significant increase in all patients groups $(\mathrm{p}<0.001 \& 0.01)$ when compared to those of the control group.

Urinary Mg concentrations showed non significant decrease in non cirrhotic and cirrhotic patients (Gr II \& Gr III) and patients with end stage liver disease group (Gr IV). 
Table (4) : Urinary $\mathrm{Cu}, \mathrm{Mg}, \mathrm{Zn}$ and $\mathrm{Ca}(\mathrm{ug} / \mathrm{ml})$ levels in control and CHC patients groups.

\begin{tabular}{|c|c|c|c|c|}
\hline \multicolumn{2}{|c|}{$\begin{array}{lll}\text { Groups } & \text { Parameters } \\
\end{array}$} & $\begin{array}{l}\text { U. Cu } \\
\text { ug/ml }\end{array}$ & $\begin{array}{l}\text { U. Zn } \\
\text { ug/ml }\end{array}$ & $\begin{array}{l}\text { U. Mg } \\
\text { ug/ml }\end{array}$ \\
\hline $\begin{array}{c}G I \\
(\mathrm{n}=22)\end{array}$ & $\begin{array}{c}\text { Range } \\
\text { Mean } \pm \text { SD }\end{array}$ & $\begin{array}{l}0.09-2.85 \\
0.98 \pm 0.76\end{array}$ & $\begin{array}{c}0-3.27 \\
0.96 \pm 0.78\end{array}$ & $\begin{array}{c}50.3-702.8 \\
226.2 \pm 148.1\end{array}$ \\
\hline $\begin{array}{c}G I I \\
(\mathrm{n}=\mathbf{3 0})\end{array}$ & $\begin{array}{c}\text { Range } \\
\text { Mean } \pm \text { SD } \\
p_{1}< \\
\% \text { change }\end{array}$ & $\begin{array}{c}0.31-17.72 \\
2.92 \pm 3.9 \\
0.05 \\
198\end{array}$ & $\begin{array}{c}0.06-12.74 \\
4.42 \pm 3.87 \\
0.001 \\
359.8\end{array}$ & $\begin{array}{c}24.9-356.5 \\
176.9 \pm 116.1 \\
\text { N.S } \\
-21.8\end{array}$ \\
\hline $\begin{array}{c}G I I I \\
(\mathrm{n}=30)\end{array}$ & $\begin{array}{c}\text { Range } \\
\text { Mean } \pm \text { SD } \\
p_{1}< \\
\% \text { change }\end{array}$ & $\begin{array}{c}0.26-2.8 \\
1.35 \pm 0.75 \\
\text { N.S } \\
37.75\end{array}$ & $\begin{array}{c}1.3-12.14 \\
3.78 \pm 3.94 \\
0.01 \\
293.77\end{array}$ & $\begin{array}{c}42.7-423.1 \\
178.7 \pm 159.8 \\
\text { N.S } \\
-21\end{array}$ \\
\hline $\begin{array}{c}G I V \\
(\mathrm{n}=\mathbf{2 2})\end{array}$ & $\begin{array}{c}\text { Range } \\
\text { Mean } \pm \text { SD } \\
p_{1}< \\
\% \text { change }\end{array}$ & $\begin{array}{c}0.12-8.34 \\
1.44 \pm 1.68 \\
\text { N.S } \\
46.94\end{array}$ & $\begin{array}{c}0.48-16.67 \\
4.08 \pm 5.25 \\
0.01 \\
325\end{array}$ & $\begin{array}{c}19.9-989.4 \\
188.6 \pm 247.4 \\
\text { N.S } \\
-16.62\end{array}$ \\
\hline
\end{tabular}

Group I: healthy (Control group)

Group II: compensated chronic liver disease (CLD) (non cirrhotic) patients

Group III: decompensated liver cirrhosis (LC) (cirrhotic) patients.

Group IV: chronic hepatitis patients with hepatocellular failure (end stage liver disease)

B. Cu (Blood copper) B. Zn (Blood zinc)

B. Fe (Blood iron) B. Se (Blood selenium)

B. $M g$ (Blood magnesium)

\section{Measurements of Ca status Table (5):}

Blood $\mathrm{Ca}$ levels showed highly significant increase in all patients groups $(\mathrm{p}<0.001 \& 0.01)$ in comparison with those of the control group.

Ionized $\mathrm{Ca}$ levels showed highly significant increase in all patients groups $(\mathrm{p}<0.001 \& 0.01)$ compared to the values of the control group.

Urinary Ca concentrations showed non significant changes in all patients group

\section{Correlations of Blood Total Free Radicals} and MDA With blood and urinary elements in Different Patients Groups:

A correlation was held between total free radicals as well as MDA analyzed for all patients groups according to Spearman correlation coefficient $\left(r_{s}\right)$ (Tables $6 \& 7$ ). This was done in a trial to find out any sort of relation between these two parameters and some blood and urinary trace elements which could assess significantly in understanding of such mechanisms and/or factors underlying such correlations 
Table (5) : Blood Ca, Urinary Ca and ionized Ca (ug/ml) in control and CHC patients groups.

\begin{tabular}{|c|c|c|c|c|}
\hline \multicolumn{2}{|c|}{ Groups $\quad$ Parameters } & $\begin{array}{c}\text { B. Ca } \\
\text { ug/g }\end{array}$ & $\begin{array}{l}\text { I. Ca } \\
\text { ug/g }\end{array}$ & $\begin{array}{l}\text { U. Ca } \\
\text { ug/ml }\end{array}$ \\
\hline $\begin{array}{c}G I \\
(\mathrm{n}=22)\end{array}$ & $\begin{array}{c}\text { Rang } \\
\text { Mean } \pm \text { SD }\end{array}$ & $\begin{array}{l}75.29-115.5 \\
95.71 \pm 10.67\end{array}$ & $\begin{array}{l}35.88-412.2 \\
167.5 \pm 101.3\end{array}$ & $\begin{array}{c}38.6-61.54 \\
49.4 \pm 5.76\end{array}$ \\
\hline $\begin{array}{c}G I I \\
(\mathrm{n}=\mathbf{3 0})\end{array}$ & $\begin{array}{c}\text { Range } \\
\text { Mean } \pm \text { SD } \\
\mathbf{p}_{1}< \\
\% \text { change }\end{array}$ & $\begin{array}{c}86.46-207.2 \\
126 \pm 27.31 \\
0.001 \\
31.64\end{array}$ & $\begin{array}{c}31.36-595.2 \\
186 \pm 162.1 \\
\text { N.S } \\
11\end{array}$ & $\begin{array}{c}48.2-115.8 \\
70.5 \pm 14.79 \\
0.001 \\
42.9\end{array}$ \\
\hline $\begin{array}{c}G I I I \\
(\mathrm{n}=30)\end{array}$ & $\begin{array}{c}\text { Range } \\
\text { Mean } \pm \text { SD } \\
p_{1}< \\
\% \text { change }\end{array}$ & $\begin{array}{c}92.33-210.8 \\
132.2 \pm 30.15 \\
0.001 \\
38.12\end{array}$ & $\begin{array}{c}45.43-319.6 \\
142.5 \pm 91.27 \\
\text { N.S } \\
-15\end{array}$ & $\begin{array}{c}51.4-130.6 \\
75.6 \pm 19.84 \\
0.001 \\
53\end{array}$ \\
\hline $\begin{array}{c}G I V \\
(\mathrm{n}=22)\end{array}$ & $\begin{array}{c}\text { Range } \\
\text { Mean } \pm \text { SD } \\
\mathbf{p}_{1}< \\
\% \text { change }\end{array}$ & $\begin{array}{c}77.52-328.9 \\
119.2 \pm 52.46 \\
0.05 \\
24.54\end{array}$ & $\begin{array}{c}22.04-890.2 \\
197.6 \pm 204.9 \\
\text { N.S } \\
18\end{array}$ & $\begin{array}{c}42.2-181.6 \\
70.3 \pm 28.9 \\
0.01 \\
42.35\end{array}$ \\
\hline
\end{tabular}

Group I: healthy (Control group)

Group II: compensated chronic liver disease (CLD) (non cirrhotic) patients

Group III: decompensated liver cirrhosis (LC) (cirrhotic) patients.

Group IV: chronic hepatitis patients with hepatocellular failure (end stage liver disease)

B. Ca (Blood calcium)

I. Ca (ionized calcium)

U. Ca (Urinary calcium)

Table (6) : Spearman correlation coefficient ( $r s)$ of blood total free radicals with some blood and urinary elements in CHC patients groups.

\begin{tabular}{|c|c|c|c|}
\hline & \multicolumn{3}{|c|}{ BLOOD TOTAL FREE RADICALS } \\
\hline Groups & Gr II & Gr III & Gr IV \\
\hline MDA & 0.38 & 0.83 & 0.58 \\
\hline B. $\mathbf{C u}$ & -0.27 & -0.17 & -0.12 \\
\hline B. $\mathbf{Z n}$ & -0.31 & $-0.44^{*}$ & -0.31 \\
\hline B. $\mathbf{~ a ~}$ & -0.08 & 0.04 & -0.21 \\
\hline B. $\mathbf{S e}$ & 0.24 & -0.17 & -0.2 \\
\hline B. $\mathbf{M g}$ & -0.11 & -0.27 & -0.13 \\
\hline B. $\mathbf{C a}$ & 0.1 & $-0.48 *$ & 0 \\
\hline I. Ca & -0.34 & $-0.47 *$ & 0.04 \\
\hline U. Cu & -0.08 & -0.25 & -0.18 \\
\hline U. $\mathbf{Z n}$ & -0.04 & -0.17 & -0.1 \\
\hline U. $\mathbf{M g}$ & 0.27 & -0.3 & 0 \\
\hline U. Ca & $0.8^{* * *}$ & -0.09 & -0.3 \\
\hline
\end{tabular}

Group I: healthy (Control group)

Group II: compensated chronic liver disease (CLD) (non cirrhotic) patients

Group III: decompensated liver cirrhosis (LC) (cirrhotic) patients.

Group IV: chronic hepatitis patients with hepatocellular failure (end stage liver disease)

$*: p<0.05$ significant correlation

**\& ***: $p<0.01$ highly significant correlation 
Detection of generated free radicals, lipid peroxidation and some trace elements status in Egyptian patients with chronic hepatitis $\mathrm{C}$.

Table (7) : Spearman correlation coefficient (rs) of malondialdehyde (MDA) with some blood and urinary elements in CHC patient groups.

\begin{tabular}{|c|c|c|c|}
\hline & \multicolumn{3}{|c|}{ MALONDIALDEHYDE (MDA) } \\
\hline Parameters & Gr II & Gr III & Gr IV \\
\hline Free radicals & 0.38 & 0.83 & 0.58 \\
\hline B. Cu & -0.17 & -0.43 & 0.1 \\
\hline B. $\mathbf{~ n ~}$ & -0.19 & $-0.44^{*}$ & -0.4 \\
\hline B. $\mathbf{~ a ~}$ & -0.18 & 0.26 & -0.03 \\
\hline B. $\mathbf{S e}$ & $0.68 * * *$ & -0.31 & 0.13 \\
\hline B. $\mathbf{M g}$ & -0.18 & 0.1 & -0.26 \\
\hline B. $\mathbf{C a}$ & $0.57 *$ & $-0.49 *$ & -0.03 \\
\hline I. Ca & $0.42 *$ & $-0.52 *$ & -0.01 \\
\hline U. Cu & 0.02 & -0.11 & -0.03 \\
\hline U. $\mathbf{Z n}$ & 0.17 & 0.17 & -0.16 \\
\hline U. $\mathbf{M g}$ & -0.17 & $-0.51^{*}$ & -0.01 \\
\hline U. Ca & -0.2 & 0.33 & -0.34 \\
\hline
\end{tabular}

Group I: healthy (Control group)

Group II: compensated chronic liver disease (CLD) (non cirrhotic) patients

Group III: decompensated liver cirrhosis (LC) (cirrhotic) patients.

Group IV: chronic hepatitis patients with hepatocellular failure (end stage liver disease)

*: $p<0.05$ significant correlation

** \& ***: $p<0.01$ highly significant correlation

\section{DISCUSSION}

Many attempts have been made to find out and discover some serological or cellular markers that may help in the clinical management and evaluation of treatments response of chronic HCV patients (Saad, 2014) because the activity of serum alanine transaminase (ALT) is variable and in most cases do not correlate with the histopathological findings of the hepatic biopsies of these patients (Hiraga et al., 2005).

In the current study, the high levels of total free radicals measured by electron spin resonance technique (ESR), and malondialdehyde (MDA) as a selected biomarker of oxidative stress coincided with the results of former studies which revealed that oxidative stress involved as a part of the pathophysiology of CHC (Romero et al., 1998), correlated with the severity of chronic hepatitis (CunninghamRumdles et al., 2002). It was a significant feature of HCV infection (Jain et al., 2002) and impaired interferon- $\alpha$ (IFN- $\alpha$ ) signaling and might cause resistance to its antiviral action in CHC patients (Di Bona et al., 2006).

Liver is a major organ susceptible to be attacked by ROS. Parenchymal cells are primary cells exposed to oxidative stress induced injury in the liver. Oxidative stress promotes the development and progression of hepatic and extrahepatic complications of HCV infection. This oxidative stress in HCV, depends on the efficacy of antioxidant defences, the nature, reactivity and site of production of ROS, the presence of iron, fatty liver, alcohol consumption and the patient's age (Choi and Ou, 2006; Li et al., 2015).

Although the general behavior of total free radicals and MDA was precisely similar and performed simultaneously, they had different correlation with trace metals parameters. Total free radicals correlated positively and significantly with, MDA in all groups except Gr II. 
Romero et al., (1998) and Mansurova et al., (2005) stated that MDA values apparently correspond with the severity of the inflammatory histopathological findings, and not with the serum ALT activity. Meanwhile, Vendemiale et al., (2001) indicated that disease severity is caused by a direct oxidative stress induction without being mediating inflammatory reactions.

Oxidative stress has been detected in almost all clinical and experimental conditions of chronic liver disease cases. (Parola and Robino, 2001) but it was found that $\mathrm{CHC}$ induces a state of hepatic oxidative stress that is more pronounced than that present in many other inflammatory liver diseases (Korenaga et al., 2005a, Mottaran et al., (2002) concluded that antigens derived from lipid peroxidation contribute to the development of immune responses associated with alcoholic liver disease.

Results of the present study are concordant with the findings of Nagoev et al., (2002) who noted that the concentration of active oxygen forms in leukocytes was maximum at the peak of the disease. Thus, free radicals or MDA can diagnose liver disease but can't differentiate its stage.

One possible explanation was cited by Choi $\boldsymbol{e t}$ al., (2004) who showed that ROS, within the biologically relevant concentration range, could suppress HCV RNA replication in hepatoma cell line (Huh7 cells). An important corollary to these findings might be that the antioxidants which are currently being investigated as potential adjunct therapy for various liver diseases (Jain et al., 2002) might in fact facilitate $\mathrm{HCV}$ replication by counteracting ROS in these patients. Anti-oxidative therapy, mainly using natural and synthetic antioxidants, represents a reasonable therapeutic approach for the prevention and treatment of liver diseases due to the role of oxidative stress in contributing to initiation and progression of hepatic damage. However, although concept of anti-oxidative therapy has been raised for decades and intensive efforts have been paid, there is a long way to go for the application of antioxidants in liver disease (Li et al., 2015). .However, many studies showed a beneficial effect of antioxidants in the course of HCV infection (Loguercio and Federico, 2003; Melhem et al., 2005) while others didn't show this beneficial effect (Takagi et al., 2003; Saeian $\boldsymbol{e t}$ al., 2004).

In the present study, both total free radicals and MDA levels were higher in non-cirrhotic than in cirrhotic patients could be proposed that they had a higher viral load than the other patient groups.

Abdalla et al., (2005), Yamaguchi et al., (2005) and Korenaga et al., (2005b) observed that HCV core protein down-regulated lipid metabolism-associated gene expression. These findings may contribute to the understanding of HCV-related steatosis, induction of ROS, and carcinogenesis.

Liver, intestine, and kidney have an important function in the regulation of trace elements metabolism (Dhawan and Goel, 1996). Further trace metals serve as cofactors for many enzymes in numerous metabolic pathways. Therefore, changes in the distribution of these essential elements can delineate a sequence of events imperative for biochemical adaptation in various stressed states. For assessing the relationships between metal loads and liver damage, several research workers have studied status of trace elements in patients with chronic liver diseases (Loguercio et al., 2001). Clinical studies reported that hepatitis $\mathrm{C}$ virus (HCV) related chronic liver disease patients at different stages of liver damage have impaired metabolism of trace elements.

A focal point, in HCV-related oxidative stress onset, is the mitochondrial failure. These organelles, known to be the "power plants" of cells, have a central role in energy production, metabolism, and metals homeostasis, mainly copper and iron. Furthermore, mitochondria are direct viral targets, because many HCV proteins associate with them. They are the main intracellular free radicals producers and tar- 
gets. Mitochondrial dysfunctions play a key role in the metal imbalance. This event, today overlooked, is involved in oxidative stress exacerbation and may play a role in HCV life cycle (Arciello et al., 2013).

In the present study, blood copper $(\mathrm{Cu})$, Calcium (Ca) and ionized $\mathrm{Ca}$ (iCa) levels were significantly elevated while Zinc (Zn) and selenium (Se) levels showed significant decrease in patients groups compared to the values of the control group. Blood iron (Fe) was unchanged in non-cirrhotic patients but it showed a significant decrease in cirrhotic and endstage liver disease. Urinary $\mathrm{Cu}$ was high in the noncirrhotic CHC patients, while urinary Zn showed a significant increase in all patients groups compared to the control group. Urinary Mg showed a significant decrease in both non-cirrhotic and cirrhotic $\mathrm{HCV}$ groups. The proportional increase of free radicals generated due to HCV infection is not associated with the same tendency of increase in $\mathrm{Cu}$ and $\mathrm{Ca}$ except urine $\mathrm{Cu}$ in non cirrhotic patients. Although $\mathrm{Ca}$ and iCa were significantly increased there was a negative correlation between them and total free radicals. On the other hand, MDA correlated positively and significantly with $\mathrm{Se}, \mathrm{Ca}$ and iCa in non cirrhotic patients. The ideal relationship was between either total free radicals or MDA with blood zinc. It was found inverse relationship in cirrhotic patients indicating severe consequences.

Nazir et al., (2013) concluded that serum trace elements profile reflected a significant statistical variation in $\mathrm{HCV}$ patients as compared to healthy individuals.

The results of present study was in accordance with the result of Qasim who found that serum copper concentration is higher in chronic hepatitis $\mathrm{C}$ patients as compared to healthy control groups, while the serum zinc concentrations were significantly lower in chronic hepatitis $\mathrm{C}$ patients than healthy control groups. Marchesini et al., (1996) found that the Zinc deficiency is common in patients who have advanced cirrhosis when there is liver dam- age. Nagamine reported that, the patients responded completely to interferon therapy were found to have a higher serum $\mathrm{Zn} / \mathrm{Cu}$ ratio than the patients who did not respond to interferon. Therefore, they advised $\mathrm{Zn}$ administration as an adjunct to interferon therapy in chronic HCV infections (Nagamine et al., 1997). They proposed that $\mathrm{Zn}$ increased antiviral effect and in turns response to interferon therapy.

The results of the present study coincide with those stated by Ko et al. (2005) who observed that the levels of $\mathrm{Zn}$ and Se in plasma and erythrocytes of HCV-infected patients significantly decreased and $\mathrm{Cu}$ levels were significantly higher than those in the control group. Nevertheless, alterations of these micronutrients concentrations in plasma and erythrocytes varied in different magnitudes.

Glutathione (GSH), a key antioxidant, able to suppress $\mathrm{Cu}$ toxicity through its binding to this metal, maintains it in a reduced state and avoids its redox cycling (Mattie and Freedman, 2004). GSH decrease, associated with $\mathrm{Cu}$ deregulation, may play a key role in the HCV-related OS onset. So, the OS induced by HCV promotes the onset of a dangerous loop involving, once again, mitochondrial damage; hence, the deranged homeostasis of metals may enhance ROS production and mitochondrial failure, which may participate in the alteration of metal homeostasis. Mitochondria, in fact, play a key role in the maintenance of $\mathrm{Cu}$ and $\mathrm{Fe}$ homeostasis (Leary, 2010; Huang et al., 2011).

Ebara et al. (2003) and Lin et al. (2006) observed that $\mathrm{Cu}$ accumulation and not $\mathrm{Fe}$ or $\mathrm{Zn}$ in fibrotic livers caused by $\mathrm{CHC}$ may contribute to hepatic injury. The real mechanism was not known, but excess $\mathrm{Cu}$ may damage the liver by oxidative stress (Fisher and Naughton, 2003; Klein et al., 2003). It was reported that inflammatory cytokines are higher in $\mathrm{HCV}$-infected individuals and increased $\mathrm{Cu}$ levels might result from inflammatory responses and they are directly related to the pathology developed in the liver by HCV (Razzaq and Malik, 2014). Research- 
ers found that phlebotomy or dietary iron restriction decreases oxidative stress and lipid peroxidation in CHC patients (Paracha et al., 2013).

The decrease in serum $\mathrm{Zn}$ levels was explained by decreased intake of dietary $\mathrm{Zn}$, disturbed intestinal absorption of $\mathrm{Zn}$, decreased serum albumin as a carrier of $\mathrm{Zn}$, decreased storage of $\mathrm{Zn}$ in liver, and increased urinary excretion of $\mathrm{Zn}$. These assumptions can also be applied to decreased tissue $\mathrm{Zn}$ content (McClain et al., 1988).

In early research of Aaseth et al. (1990); Thuluvath and Triger (1992) was found that the decrease of Se in cirrhotic patients documented both in alcoholics and nonalcoholics was attributed primarily to a poor intake and was not related to degree of liver function. More recently this idea altered as observed by Loguercio et al. (2001) and Ko et al. (2005) who revealed that liver plays a central role in trace element metabolism. Therefore, the alternation of its structure and function typical of cirrhosis may alter the intrahepatic utilization of trace element as well as their emission in the blood and not induced by nutritional status or intestinal malabsorption and so, the decreased $\mathrm{Zn}$ and Se levels. The main cause of blood decrease in selenium and zinc attributed to liver impairment in HCV related chronic liver disease, independently of the nutritional status, whereas the associated malnutrition affects the ferrous levels only (Ioannou et al., 2003).

Also, Czuczejko et al. (2003) reported that decreasing levels of $\mathrm{Zn}$, Se, or increasing $\mathrm{Cu}$ levels were also noted in sera of hepatitis cases. This conclusion was previously proposed by Nandi $\boldsymbol{e t} \boldsymbol{a l}$. (1989) who indicated that serum and urinary zinc levels could be used as a prognostic indicator in fulminant hepatic failure (FHF).

Numerous studies have documented low levels of selenium in hepatitis $\mathrm{C}$ patients, and when it used in conjunction with other antioxidants, it has been shown to reduce oxidative stress in the liver (Naga- mine et al., 1997). In the study of Kolachi et al. (2011), they found that the serum and blood levels of Se and Zn in HCV patients were significantly lower than those of the referent subjects.

Iron has also been found to play an important role in oxidative stress. Fenton's reaction, which causes the conversion of low active $\mathrm{H}_{2} \mathrm{O}_{2}$ into potential hydroxyl and peroxide radicals, helps iron ions in ROS production (Ryter et al., 2007; Weinreb et al., 2010). Iron is present in many parts of the body and liver is one of the main sites of storage (Ganz and Nemeth, 2012; Pantopoulos et al., 2012), thereby increased iron ions could result in more oxidative stress in liver cells. Researchers found that phlebotomy or dietary iron restriction decreases oxidative stress and lipid peroxidation in $\mathrm{CHC}$ patients (Paracha et al., 2013).

Results of the present work are in agreement with those of Loguercio et al. (2001) who reported a decrease of serum iron in cirrhotic patients, whereas Sikorska et al. (2003); Metwally et al. (2004); Shan et al. (2005) recorded an obvious increase was in both liver and serum $\mathrm{Fe}$ of $\mathrm{CHC}$ patients.

Thus, levels of blood Fe received from pretreated patients might not be a proper marker for the iron status in patients with $\mathrm{CHC}$ infection. Although the precise causes remain to be elucidated, there is evidence that cytokines might alter the levels of serum trace elements in viral hepatitis (Yano et al., 2004). Hepatic iron deposit has been identified as one of the risk factors of progression of liver disease (Nozic $\boldsymbol{e t}$ al., 2005). Yano et al. (2004) and Nozic et al. (2005) demonstrated that iron depletion and zinc supplementation may improve the response of chronic hepatitis $\mathrm{C}$ patients to interferon treatment. Whereas, Gattoni et al. (2006) didn't support a role for iron depletion in patients with chronic HCV infection.

The data of Morbitzer and Herget (2005) pointed to a more direct antiviral function of the selenoprotein GI-GPx in HCV infection. Because 
deficiency in dietary selenium results in decreased levels of selenoproteins, thus compromising biological processes that are maintained by these proteins, it will be interesting to investigate whether selenium lack supports HCV spreading in patients.

The present results are in accordance with those reported by Jain et al. (2002) who stated that the moderate but significant reduction in selenium levels in the non-cirrhotic group reflecting the early stage of disease. They added that the cirrhotic group having even lower levels. Interestingly, HCV itself has been shown to encode a selenium-dependent glutathione peroxidase gene (Zhang et al., 1999) presumably as a protection against attack from free radicals generated by inflammatory cells.

Selenocysteine proteins do not only function to protect against oxidative stress but seem to have other crucial roles in maintaining a healthy physiology of the liver (Carlson et al., 2004). Selenium was proposed to have anticarcinogenic functions, and recently it was shown that in progressed stages of colorectal cancer expression of selenoprotein GI-GPx was decreased (Miyamoto et al., 2003). Selenium has also been implicated in enhancing immune functions and thereby slowing the progression of AIDS in human immunodeficiency virus-positive patients (Gladyshev et al., 1999).

Koivisto et al. (2002) stated that there are no studies on magnesium status in chronic cirrhotics which may be in depletion.

In the present study Mg levels showed non significant change in all patients groups. These results were in contrast with those of Wang et al. (2004) who concluded that there was calcium and magnesium deficiencies in the patients with uncompensative cirrhosis and compensative cirrhosis.

Also, Kamochi et al. (2002) observed that profound ionized hypomagnesemia was induced by plasma exchange in liver failure patients. Koivisto et al. (2002) observed that chronic terminal cirrhotics are $\mathrm{Mg}$ depleted which should be taken into account in case of liver transplantation and also in other interventions.

Rocchi et al. (1994) observed that the plasma levels of $\mathrm{Zn}$ and $\mathrm{Mg}$ and urine levels of $\mathrm{Mg}$ were found to be reduced. They added that plasma $\mathrm{Zn}$ correlated inversely, and urine $\mathrm{Zn}$ directly, with the severity of the disease, rather than with alcohol consumption or treatment with diuretics. Protein metabolism impairment would appear to affect the plasma transport of $\mathrm{Zn}$ rather than its overall availability in the organism; the opposite was found in the case of $\mathrm{Mg}$, the availability of which appeared to be reduced.

In the present study, total and ionized Ca levels in blood were significantly elevated in all patients groups.

$\mathrm{HCV}$ replication is associated with the endoplasmic reticulum (ER), where the virus causes stress (Ciccaglione et al., 2005). Cells cope with ER stress by activating an adaptive program called the unfolded protein response (UPR), which alleviates this stress by stimulating protein folding and degradation in the ER and down-regulating overall protein synthesis. Tardif et al. (2005) suggested that HCV also alters ER calcium homeostasis, inducing oxidative stress. Wang and Weinman (2006) observed that core protein increased $\mathrm{Ca}(2+)$ uptake into isolated mitochondria. These results assume that interaction of core protein with mitochondria and subsequent oxidation of the glutathione pool and complex I inhibition may be an important cause of the oxidative stress seen in $\mathrm{CHC}$.

Hypercalcemia caused by advanced chronic liver disease (CLD) without hepatic neoplasia is uncommonly reported and poorly understood condition (Kuchay et al., 2016). One of the consequences of the ER overload response is the activation of STAT3 via $\mathrm{Ca}^{2+}$ signaling and induction of ROS, triggering an ER-to-nucleus signal transduction pathway (Gong et al., 2001). 
An overwhelming number of studies supported the role of free radicals in the initiation and progression of multistage carcinogenesis (Sun, 1990). Consistent with this idea, free radical scavengers and antioxidant enzymes are down-regulated in tumor cells (Corrocher et al., 1986). Bergqvist et al. (2003) indicated that expression of $\mathrm{HCV}$ in infected $\mathrm{T}$ lymphocytes may contribute to the establishment of persistent infections by inducing $\mathrm{Ca} 2+$ oscillations that regulate both the efficacy and information content of $\mathrm{Ca} 2+$ signals and are ultimately responsible for induction of gene expression and functional differentiation.

Taylor et al. (2003) concluded that HCV core protein localizes to mitochondria, associates with the mitochondrial outer membrane, increases mitochondrial $\mathrm{Ca}^{2+}$ uptake, and causes oxidation of the glutathione pool. This change in mitochondrial redox state inhibits complex I activity, further increases ROS production and can create positive feedback loop.

The present results of high blood levels of ionized $\mathrm{Ca}$ may causes osteoporosis which seen in chronic liver disease. The prevalence of osteoporosis among patients with chronic liver diseases ranges from $10 \%$ to $60 \%$ (Gonzalez-Calvin et al., 1993).

It was concluded that liver functional impairment as well as oxidative stress associated with free radical generation may alter the metabolism of trace elements, in particular, zinc and copper. Our findings imply that the levels of elements $(\mathrm{Cu}, \mathrm{Zn}, \mathrm{Fe}, \mathrm{Se}$, $\mathrm{Mg}, \mathrm{Ca}$ and iCa) might serve as biochemical parameters in the identification status and the degree levels of diseased patients with HCV as well as the predicted consequences of the diseases.

\section{ACKNOWLEDGEMENT}

Our great thanks to The Late Professor Mohamed S. Al-Harty, Professor of Medical Chemistry, Faculty of Medicine, Al-Azhar University for his kind help, great support and cooperation during this work.

\section{REFERENCES}

- $\quad$ Aaseth, J.; Ringstad, J.; Bell, H. and Thomassen, Y. (1990): Alcohol, Trace Elements, and liver dysfunction. In: Trace Elements in Clinical Medicine, Tomita, H. (Ed.), Springer-Verlag, Tokyo, pp. 79.

- Abdalla, M.Y.; Ahmad, I.M.; Spitz, D.R.; Schmidt, W.N. and Britigan, B.E. (2005): Hepatitis C viruscore and non structural proteins lead to different effects on cellular antioxidant defenses. J. Med. Virol., 76(4): 489 .

- Arciello, M.; Gori, M.and Balsano, C. (2013): Mitochondrial Dysfunctions and Altered Metals Homeostasis: New Weapons to Counteract HCV-Related Oxidative Stress. Oxid. Med. Cell. Longev., Article ID 971024, http://dx.doi.org/10.1155/2013/971024.

- Attia, H.A.M.; Zekri, A.N.; Goudsmit, J.; Boom, R.; Khaled, H.M; Mansour, M.T.; Dewaf, F.; Alam El-Din, H.M. and Sol, C.J.A. (1996): Diverse Patterns of Recognition of Hepatitis C Core and none Structural Antigens by Antibodies Present in Egypt Cancer Patients and Blood Donors. J. Clin. Microbiol., 34(11): 2665.

- Bergqvist, A.; Sundstrom, S.; Dimberg, L.Y.; Gylfe, E. and Masucci, M.G. (2003): The hepatitis $\mathrm{C}$ virus core protein modulates $\mathrm{T}$ cell responses by inducing spontaneous and altering T-cell receptortriggered Ca2+ oscillations. J. Biol. Chem., 278(21): 18877.

- Boffi, F.M.; Ozaki, J.; Matsuki, N.; Inaba, M.; Desmaras, E. and Ono, K. (2002): Effects of Chemical Ischemia on Purine Nucleotides, Free Radical Generation, Lipids Peroxidation and Intracellular Calcium Levels in C2C12 Myotube Derived from Mouse Myocytes. J. Vet. Med. Sci., 64(6): 483.

- Bourre, J.M. (2006): Effects of nutrients (in food) on the structure and function of the nervous system: update on dietary requirements for brain. Part 1: micronutrients. J. Nutr. Health Aging., 10(5): 377. 
- Bygrave, F.L. and Benedetti, A. (1993): Calcium: its modulation in liver by cross-talk between the actions of glucagon and calcium-mobilizing agonists. Biochem. J., 296: 1: 1.

- Carlo, C.; Daniela, P. and Giancarlo, C. (2003): Iron depletion and response to interferon in chronic hepatitis C. Hepatogastroenterology, 50: 1467.

- Carlson, B.A.; Novoselov, S.V.; Kumaraswamy, E.; Lee, B.J.; Anver, M.R.; Gladyshev, V.N. and Hatfield, D.L. (2004): Specific excision of the selenocysteine tRNA[Ser]Sec (Trsp) gene in mouse liver demonstrates an essential role of selenoproteins in liver function. J. Biol. Chem., 27; 279(9): 8011.

- Choi, J. and Ou, J.H. (2006): Mechanisms of Liver Injury. III. Oxidative stress in the pathogenesis of hepatitis C virus. Am. J. Physiol. Gastrointest. Liver Physiol., 290(5): G847.

- Choi, J.; Lee, K.J.; Zheng, Y.; Yamaga, A.K.; Lai, M.M. and Ou, J.H. (2004): Reactive oxygen species suppress hepatitis $\mathrm{C}$ virus RNA replication in human hepatoma cells. Hepatology, 39(1): 81.

- Ciccaglione, A.R.; Costantino, A.; Tritarelli, E.; Marcantonio, C.; Equestre, M.; Marziliano, N. and Rapicetta, M. (2005): Activation of endoplasmic reticulum stress response by hepatitis $\mathrm{C}$ virus proteins. Arch. Virol., 150(7): 1339.

- Contreras-Zentella,

M.L. and Hernández-Muñoz, R. (2016): Is Liver Enzyme Release Really Associated with Cell Necrosis Induced by Oxidant Stress?, Oxid. Med. Cell Longev., 2016, Article ID 3529149, . doi: $10.1155 / 2016 / 3529149$.

- Corrocher, R.; Casaril, M.; Bellisola, G.; Gabrielli, G.B.; Nicoli, N.; Guidi, G.C. and De Sandre, G. (1986): Severe impairment of antioxidant system in human hepatoma. Cancer, 58(8): 1658.

- Cunningham-Rumdles, S.; Ahrn, S.; Abuav-Nussbaum, R. and Dnistrian, A. (2002): Development of immunocompetence: Role of micronutrients and microorganisms. Nutr. Rev., 60: S68.

- Czuczejko, J.; Zachara, B.A.; Staubach-Topc- zewska, E.; Halota, W. and Kedziora; J. (2003): Selenium, glutathione and glutathione peroxidase in blood of patients with chronic liver diseases. Acta Biochim. Polon., 50: 1147.

- Dhawan, D. and Goel, A. (1996): Further evidence for zinc as a hepatoprotective agent in rat liver toxicity. Exp. Mol. Pathol., 63: 110.

- Di Bona, D.; Cippitelli, M.; Fionda, C.; Camma, C.; Licata, A.; Santoni, A. and Craxi, A. (2006): Oxidative stress inhibits IFN-alpha-induced antiviral gene expression by blocking the JAK-STAT pathway. J. Hepatol., 45(2): 271.

- $\quad$ Ebara, M.; Fukuda, H.; Hatano, R.; Yoshikawa, M.; Sugiura, N.; Saisho, H.; Kondo, F. and Yukawa, M (2003): Metal contents in the liver of patients with chronic liver disease caused by hepatitis $\mathrm{C}$ virus. Reference to hepatocellular carcinoma. Oncology., 65(4): 323.

- $\quad$ Fisher, A.E. and Naughton, D.P. (2003): Vitamin $\mathrm{C}$ contributes to inflammation via radical generating mechanisms: a cautionary note. Med. Hypotheses, 61: 657.

- $\quad$ Frank, C.; Mohamed, M.K.; Strickland, G.T.; Lavanchy, D.; Arthur, R.R.; Magder, L.S.; El Khoby, T.; Abdel-Wahab, Y.; AlyOhn, E.S.; Anwar, W., et al. (2000): The role of parenteral antischistosomal therapy in the spread of hepatitis $\mathrm{C}$ virus in Egypt. Lancet., 355 (9207): 887.

- Ganz, T. and Nemeth, E. (2012): Hepcidin and iron homeostasis. Biochim. Biophys. Acta, 1823(9):1434.

- Gattoni, A.; Parlato, A.; Vangieri, B.; Bresciani, M.; Derna, R. and Baldassarre, R. (2006): Role of hemochromatosis genes in chronic hepatitis C. Clin. Ter., 157(1): 61 .

- Gladyshev, V.N.; Stadtman, T.C.; Hatfield, D.L. and Jeang, K. (1999): Levels of major selenoproteins in $\mathrm{T}$ cells decrease during HIVinfection and low molecular mass selenium compounds increase. Proc. Natl. Acad. Sci. USA, 96: 835.

- Gohn, A. (1986): ESR and Elementary Particle Applications, John Wiley, New York. 
- Gong, G.; Waris, G.; Tanveer, R. and Siddiqui, A. (2001): Human hepatitis $C$ virus NS5A protein alters intracellular calcium levels, induces oxidative stress, and activates STAT-3 and NF-кB. Proc. Natl. Acad. Sci. USA, 98: 9599.

- Gonzalez-Calvin, J.L.; Garcia-Sanchez, A.; Bellot, V.; Munoz-Torres, M.; Raya-Alvarez, E. and Salvatierra-Rios, D. (1993): Mineral metabolism, osteoblastic function and bone mass in chronic alcoholism. Alcohol Alcohol., 28(5): 571.

- Heckly, R.J. (1972): Free radicals in dry tissues. In: Swartz, H.M.; Bolton, J.R and Borg, D.C. (Eds.), Biological applications of electron spin resonance. Wiley-Interscience, a division of John Wiley \& Sons, Inc. New York, London, Sydney, Toronto.

- Heckly, R.J. (1976): Free Radicals in Dry Biological Systems. In: Pryor, W.A. (ed.), "Free radicals in biology". Volume II. Academic press. New York, San Francico, London. A subsidiary of Harcourt Brace. Jovanovich, Publishers.

- Hiraga, N.; Suzuki, F.; Akuta, N.; Suzuki, Y.; Sezaki, H.; Hosaka, T.; Someya, T.; Kobayashi, M.; Saitoh, S.; Arase, Y.; Ikeda, K.; Kobayashi, M.; Matsuda, M.; Watabiki, S.; Satoh, J. and Kumada, H. (2005): Clinical and Virological Characteristics of Untreated Patients With Chronic Hepatitis C Who Develop Serum Alanine Aminotransferase Flare-up. J. Med. Virol., 75: 240.

- Huang, M.L.H.; Lane, D.J.R. and Richardson, D.R. (2011): Mitochondrial mayhem: the mitochondrion as a modulator of iron metabolism and its role in disease. Antioxid. Redox Signal, 15(12): 3003.

- Ioannou, G.N.; Dominitz, A.A.; Weiss, N.S.; Heagerty, P.J. and Kowdley, K.V. (2003): Differences in the relationship between hepatitis $\mathrm{C}$ infection and iron stores. Hepatology, 37(4): 795.

- Ivanov, A.V.; Bartosch, B.; Smirnova, O.A.; Isaguliants, M.G. and Kochetkov, S.N. (2013): HCV and Oxidative Stress in the Liver. Viruses, 5(2): 439.

- Jain, S.K.; Pemberton, P.W.; Smith, A.; McMahon, R.F.; Burrows, P.C.; Aboutwerat, A. and
Warnes, T.W. (2002): Oxidative stress in chronic hepatitis C: not just a feature of late stage disease. $J$. Hepatol., 36: 805.

- Kalkan, A.; Bulut, V.; Avci, S.; Celik, I. and Bingol, N.K. (2002): Trace elements in viral hepatitis. $J$. Trace Elem. Med. Biol., 16(4): 227.

- Kamochi, M.; Aibara, K.; Nakata, K.; Murakami, M.; Nandate, K.; Sakamoto, H.; Sata, T. and Shigematsu, A. (2002): Profound ionized hypomagnesemia induced by therapeutic plasma exchange in liver failure patients. Transfusion., 42(12): 1598.

- Klein, D.; Lichtmannegger, J.; Finckh, M. and Summer, K.H. (2003): Gene expression in the liver of Long-Evans cinnamon rats during the development of hepatitis. Arch. Toxicol., 77: 568.

- Ko, W.; Guo, C.; Yeh, M.; Lin, L.; Hsu, G.W.; Chen, P.; Luo, M. and Lin, C. (2005): Blood micronutrient, oxidative stress, and viral load in patients with chronic hepatitis C. World J. Gastroenterol., 11(30): 4697.

- Kohchi, C.; Inagawa, H.; Nishizawa, T.; Soma, G. (2009): ROS and innate immunity. Anticancer Res., 29:817.

- Koivisto, M.; Valta, P.; Hockerstedt, K. and Lindgren, L. (2002): Magnesium depletion in chronic terminal liver cirrhosis. Clin. Transplant., 16(5): 325.

- Kolachi, N.F.; Kazi, T.G.; Afridi, H.I.; Kazi, N.; Kandhro, G.A.; Shah, A.Q.; Baig, J.A.; Wadhwa, S.K.; Khan, S.; Shah, F.; Jamali, M.K. and Balal, M. (2011): Distribution of Copper, Iron, and Zinc in Biological Samples (Scalp Hair, Serum, Blood, and Urine) of Pakistani Viral Hepatitis (A-E) Patients and Controls. Biol. Trace Elem. Res., 143: 116.

- Korenaga, M.; Okuda, M.; Otani, K.; Wang, T.; Li, Y. and Weinman, S.A. (2005a): Mitochondrial dysfunction in hepatitis C. J. Clin. Gastroenterol., 39(4 Suppl 2): S162.

- Korenaga, M.; Wang, T.; Li, Y.; Showalter, L.A.; Chan, T.; Sun, J. and Weinman, S.A. (2005b): Hepatitis C Virus Core Protein Inhibits Mitochondrial Electron Transport and Increases Reactive Oxygen 
Species (ROS) Production. J. Biol. Chem., 280(45): 37481.

- Kuchay, M.S.; Mishra, S.K., Farooqui, K.J.; Bansal, B.; Wasir, J.S.; Mithal, A. (2016): Hypercalcemia of advanced chronic liver disease: a forgotten clinical entity. Clin. Cases Miner. Bone. Metab., 13(1): 15 .

- Leary, S.C. (2010): Redox regulation of SCO protein function: controlling copper at a mitochondrial crossroad. Antioxid. Redox Signal, 13(9): 1403.

- Li, S.; Tan, H.; Wang, N.; Zhang, Z.; Lao, L.; Wong, C. and Feng, Y. (2015): The Role of Oxidative Stress and Antioxidants in Liver Diseases. Int. J. Mol. Sci., 16: 26087.

- Lin, C.C.; Huang, J.F.; Tsai, L.Y. and Huang, YL. (2006): Selenium, iron, copper, and zinc levels and copper-tozinc ratios in serum of patients at different stages of viral hepatic diseases. Biol. Trace Elem. Res., 109(1): 15.

- Loguercio, C. and Federico, A. (2003): Oxidative stress in viral and alcoholic hepatitis. Free Radic. Biol. Med., 34(1): 1.

- Loguercio, C.; De Girolamo, V.; Federico, A.; Feng, S.L.; Crafa, E.; Cataldi, V.; Gialanella, G.; Moro, R.; Del Vecchio, B.C. (2001): Relationship of blood trace elements to liver damage, nutritional status, and oxidative stress in chronic nonalcoholic liver disease. Biol. Trace Elem. Res., 81: 245.

- Mansurova, F.Kh.; Mutikhova, Kh.Sh. and Olimova, S.O. (2005): [Lipid peroxidation and antioxidative protection in patients with chronic type $\mathrm{C}$ hepatitis. Klin. Med. (Mosk), 83(5): 39.

- Marchesini, G.; Fabbri, A.; Bianchi, G.; Brizi, M. and Zoli, M. (1996): Zinc supplementation and amino acid-nitrogen metabolism in patients with advanced cirrhosis. Hepatology, 23(5): 1084.

- Mattie, M.D. and Freedman, J.H. (2004): Copperinducible transcription: Regulation by metal- and oxidative stress-responsive pathways. Am. J. Physiol. Cell Physiol., 286(2): C293,
- McClain, C.J.; Adams, L. and Shedlofsky, S. (1988): Zinc and the gastrointestinal system. In: essential and toxic elements in health and disease. Parasad, A.S. (Ed.), Liss, New York, pp. 55.

- Melhem, A.; Stern, M.; Shibolet, O.; Israeli, E.; Ackerman, Z.; Pappo, O.; Hemed, N.; Rowe, M.; Ohana, H.; Zabrecky, G.; Cohen, R. and Ilan, Y. (2005): Treatment of chronic hepatitis $C$ virus infection via antioxidants: results of a phase I clinical trial. J. Clin. Gastroenterol., 39(8): 737.

- Meran, L.; Sirmatel, F.; Ahi, S. and Tarakcioglu, M. (2004): Plasma copper and zinc levels in chronic viral hepatitis. Saudi Med. J., 25(8): 1066

- Metwally, M.A.; Zein, C.O. and Zein, N.N. (2004): Clinical significance of hepatic iron deposition and serum iron values in patients with chronic hepatitis $\mathrm{C}$ infection. Am. J. Gastroenterol., 99: 286.

- Milton, J.S., Corbert, J.J. and Me Teer, P.M.

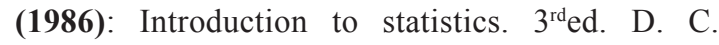
Healthy and Company, Canada.

- Miyamoto, Y.; Koh, Y.H.; Park, Y.S.; Fujiwara, N.; Sakiyama, H.; Misonou, Y.; Ookawara, T.; Suzuki, K.; Honke, K. and Taniguchi, N. (2003): Oxidative stress caused by inactivation of glutathione peroxidase and adaptive responses. Biol. Chem., 384(4): 567.

- Mohammed, M.A.; AbdEImaksouda, M.D.; Abd El Maksouda, N.; El-Mezayenb, H.A. and El-Garaamc, H. (2012): Serum levels of trace elements in Egyptian patients with chronic hepatitis $\mathrm{C}$ under interferon therapy. J. Gene. Eng. Biotechnol., 10: 81.

- Mohammed, N.; Abbasi, M.S.; Hasani, S.R.; Mohebi, M.R. and Zali, J. (2010): Serum levels of trace elements in Egyptian patients with chronic hepatitis C under interferon therapy. Hepatitis, 10: 62.

- Morbitzer, M. and Herget, T. (2005): Expression of Gastrointestinal Glutathione Peroxidase Is Inversely Correlated to the Presence of Hepatitis C Virus Subgenomic RNA in Human Liver Cells. J. Biol. Chem., 280(10): 8831 .

- Mottaran, E.; Stewart, S.F.; Rolla, R.; Vay, D.; 
Cipriani, V.; Moretti, M.,; Vidali, M.; Sartori, M.; Rigamonti, C.; Day, C.P. and Albano, E. (2002): Lipid peroxidation contributes to immune reactions associated with alcoholic liver disease. Free Radic Biol. Med., 32(1): 38.

- $\quad$ Nagamine, T.; Takagi, H.; Hashimoto, Y.; Takayama, H.; Shimoda, R.; Nomura, N.; Suzuki, K.; Mori, M. and Nakajima, K. (1997): The possible role of zinc and metallothionein in the liver on the therapeutic effect of IFN- $\alpha$ to hepatitis $\mathrm{C}$ patients. Biol. Trace Elem. Res., 58: 65.

- Nagoev, B.S.,; Abidov, M.T. and Ivanova, M.R. (2002): LPO and free-radical oxidation parameters in patients with acute viral hepatitis. Bull. Exp. Biol. Med., 134(6): 557.

- $\quad$ Nandi, S.S.; Chawla, Y.K.; Nath, R. and Dilawari, J.B. (1989): Serum and urinary zinc in fulminant hepatic failure. J. Gastroenterol. Hepatol., 4(3): 209.

- $\quad$ Nazir, F.; Sarfraz, A.R.; Qudoos, A. and Riaz, R. (2013): Trace Elements Profile of Hepatitis C Patients in Faisalabad, Pakistan. WASJ, 28(8): 1093.

- $\quad$ Nicotera, P.; Hartzell, P.; Baldi, C.; Svensson, S.A.; Bellomo, G. and Orrenius, S. (1986): Cystamine induces toxicity in hepatocytes through the elevation of cytosolic $\mathrm{Ca} 2+$ and the stimulation of a nonlysosomal proteolytic system. J. Biol. Chem., 261(31): 14628.

- $\quad$ Nozic, D.; Balint, B.; Stankovic, N.; Dimitrijevic, J. and Neskovic, G. (2005): Significance of iron reduction for the therapy of chronic hepatitis C. Vojnosanit Pregl., 62(2): 161.

- $\quad$ Pantopoulos, K.; Porwal, S.K.; Tartakoff, A. and Devireddy, L. (2012): Mechanisms of mammalian iron homeostasis. Biochemistry, 51(29): 5705.

- Paracha, U.Z.; Kaneez, F., Alqahtani, M., Adeel, C.; Abuzenadah, A.; Damanhouri, G. and Qadri, I. (2013): Oxidative stress and hepatitis $\mathrm{C}$ virus. $\mathrm{Vi}$ rology, 10: 251 .

- $\quad$ Parola, M. and Robino, G. (2001): Oxidative stress related molecules and liver fibrosis. J. Hepatol., 35: 297.
- Pascual, E.C.; Goodman, B.A. and Yeretzian, C. (2002): Characterization of free radicals in soluble coffee by electron paramagnetic resonance spectroscopy. J. Agric. Food Chem., 50(21): 6114.

- $\quad$ Rashed, M.N. (2011): The role of trace elements on hepatitis virus infections: A review. J. Trace Elem. Med. Biol., 25: 181.

- $\quad$ Razzaq, Z. and Malik, A. (2014): Viral load is associatedwith abnormal serumlevels of micronutrients and glutathione and glutathione-dependent enzymes in genotype $3 \mathrm{HCV}$ patients. BBA Clin., 2: 72-78

- $\quad$ Rocchi, E.; Borella, P.; Borghi, A.; Paolillo, F.; Pradelli, M.; Farina, F. and Casalgrandi, G. (1994): Zinc and magnesium in liver cirrhosis. Eur. J. Clin. Invest., 24(3): 149.

- Romero, F.J.; Bosch-Morell, F.; Romero, M.J.; Jareño, E.J.; Romero, B.; Marín, N. and Romá, J . (1998): Lipid peroxidation products and antioxidants in human disease. Environ. Health Perspect., 106(5): 1229.

- $\quad$ Ryter, S.W.; Kim, H.P.; Hoetzel, A.; Park, J.W.; Nakahira, K.; Wang, X. and Choi, A.M. (2007): Mechanisms of cell death in oxidative stress. Antioxid. Redox Signal, 9(1):49.

- Saad, E. A. (2014): Non-invasive Assessment of Liver Fibrosis Using Serum Markers. J. Pharm. Chem. Biol. Sci., 2(2):59.

- $\quad$ Saeian, K.; Bajaj, J.S.; Franco, J.; Knox, J.F.; Daniel, J.; Peine, M.D.; Varma, R.R. and Ho, S. (2004): High-dose vitamin E supplementation does not diminish ribavirin-associated haemolysis in hepatitis $\mathrm{C}$ treatment with combination standard alphainterferon and ribavirin. Aliment Pharmacol. Ther., 20(10): 1189 .

- $\quad$ Sebastiani, G.; Vario, A.; Ferrari, A.; Pistis, R.; Noventa, F. and Alberti, A. (2006): Hepatic iron, liver steatosis and viral genotypes in patients with chronic hepatitis C. J. Viral Hepatitis, 13(3): 199.

- Shan, Y., Lambrecht, R.W. and Bonkovsky, H.L. (2005): Association of hepatitis $C$ virus infection with serum iron status: analysis of data from the third 
National Health and Nutrition Examination Survey. Clin. Infect. Dis., 40(6): 834.

- Sikorska, K.; Stalke, P.; Lakomy, E.A.; Michalska, Z.; Witczak-Malinowska, K. and Stolarczyk, J. (2003): Disturbances of iron metabolism in chronic liver diseases. Med. Sci. Monit., 9(3): 64.

- Sun, Y. (1990): Free radicals, anti-oxidant enzymes, and carcinogenesis. Free Radical Biol. Med., 8: 583.

- $\quad$ Takagi, H.; Kakizaki, S.; Sohara, N.; Sato, K.; Tsukioka, G.; Tago, Y.; Konaka, K.; Kabeya, K.; Kaneko, M.; Takayama, H.; Hashimoto, Y.; Yamada, T.; Takahashi, H.; Shimojo, H.; Nagamine, T. and Mori, M. (2003): Pilot clinical trial of the use of alpha - tocopherol for the prevention of hepatocellular carcinoma in patients with liver cirrhosis. Int. J. Vitam. Nutr. Res., 73(6): 411.

- Tardif, K.D.; Waris, G. and Siddiqui, A. (2005): Hepatitis C virus, ER stress, and oxidative stress. Trends Microbiol., 13 (4): 159.

- Taylor, E.R.; Hurrell, F.; Shannon, R.J.; Lin, T.K., Hirst, J. and Murphy, MP. (2003): Reversible glutathionylation of complex I increases mitochondrial superoxide formation. J. Biol. Chem., 278(22): 19603.

- Thuluvath, P.J. and Triger, D.R. (1992): Selenium in chronic liver disease. J. Hepatol., 14(2-3): 176.

- Vendemiale, G.; Grattagliano, I.; Portincasa, P.; Serviddio, G.; Palasciamo, G. and Altomare, E. (2001): Oxidative stress in symptom-free HCV carriers: relation with ALT flare-up. Eur. J. Clin. Invest., 31: 54 .

- Wang, J.; Holmes, T.H.; Cheung, R.; Greenberg, H.B. and He; X.S. (2004): Expression of chemokine receptors on intrahepatic and peripheral lymphocytes in chronic hepatitis $\mathrm{C}$ infection: its relationship to liver inflammation. J. Infect. Dis., 190(5): 989.
- Wang, T. and Weinman, S.A. (2006): Causes and consequences of mitochondrial reactive oxygen species generation in hepatitis C. J. Gastroenterol. Hepatol., 21(3): S34.

- Weinreb, O.; Amit, T.; Mandel, S.; Kupershmidt, L. and Youdim, M.B. (2010): Neuroprotective multifunctional iron chelators: from redox-sensitive process to novel therapeutic opportunities. Antioxid. Redox Signal, 13(6):919.

- West, A.P.; Shadel, G.S.; Ghosh, S. (2011): Mitochondria in innate immune responses. Nat. Rev. Immunol., 11: 389 .

- Yamaguchi, A.; Tazuma, S.; Nishioka, T.; Ohishi, W.; Hyogo, H.; Nomura, S. and Chayama, K. (2005): Hepatitis $C$ virus core protein modulates fatty acid metabolism and thereby causes lipid accumulation in the liver. Dig. Dis. Sci., 50(7): 1361.

- Yano, M.; Hayashi, H.; Yoshioka, K.; Kohgo, Y.; Saito, H.; Niitsu, Y.; Kato, J.; Iino, S.; Yotsuyanagi, H.; Kobayashi, Y.; Kawamura, K.; Kakumu, S.; Kaito, M.; Ikoma, J.; Wakusawa, S.; Okanoue, T.; Sumida, Y.; Kimura, F.; Kajiwara, E.; Sata, M. and Ogata, K. (2004): A significant reduction in serum alanine aminotransferase levels after 3-month iron reduction therapy for chronic hepatitis $\mathrm{C}$ : a multicenter, prospective, randomized, controlled trial in Japan. J. Gastroenterol., 39(6): 570.

- Yoshioka, T.; Kawada, K.; Shimada, T. and Mori, M. (1979): Lipid peroxidation in maternal and cord blood and protective mechanism against activatedoxygen toxicity in the blood. Am. J. Obstet. Gynecol., 135(3): 372.

- Zhang, W.; Ramanathan, C.S.; Nadimpalli, R.G.; Bhat, A.A.; Cox, A.G. and Taylor, E.W. (1999): Selenium-dependent glutathione peroxidase modules encoded by RNA viruses. Biol. Trace Elem. Res., 70(2): 97. 
